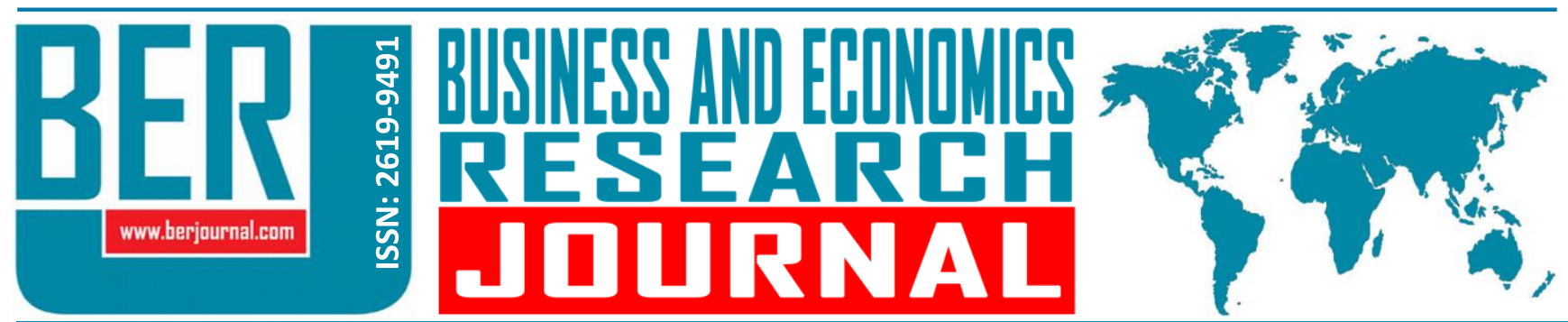

Business and Economics Research Journal Vol. 11, No. 3, 2020, pp. 793-805 doi: 10.20409/berj.2020.282

\title{
A Study on Consumers' Usage Behavior of the Bank's Mobile Payment APPs in Taiwan
}

\author{
Pih-Shuw Chen ${ }^{\mathrm{a}}$, Jia-Jan Lee ${ }^{\mathrm{b}}$, Sheng-Ju Huang ${ }^{\mathrm{c}}$, Che Liang Lin ${ }^{\mathrm{d}}$
}

Abstract: With the advancement of smart phones, the rise of mobile payments has become a new payment method for consumers. The purpose of this study is to use structural equation model to verify the factors that affect consumers' behavior in using bank's mobile payment applications (APPs), so as to provide recommendations as main reference to enhance bank's mobile payment APPs. In this study, the research subjects were consumers who have used mobile payments APPs, a total of 300 valid responses were collected. The results show that security has a significant positive impact on perceived usefulness and perceived ease of use; perceived ease of use has a significant positive impact on perceived usefulness. Both of perceived usefulness and perceived ease of use have significantly positive influences on functional consumption value. Furthermore, functional consumption value and perceived usefulness have significant positive effect on usage behavior. As a result, banks are recommended to continually increase cooperative merchants that can use their mobile payments APPs, support for various operating systems of mobile phones, facilitate transaction speeds, ensure personal information, and provide user friendly interfaces.

Keywords: Bank's Mobile Payment APPs, Security, Perceived Usefulness, Perceived Ease of Use, Functional Consumption Value

JEL: G21, G41 M31

\section{Introduction}

With the rapid change and development of the information and communication technology (ICT), smartphones have become popular. According to a survey by the National Communications Commission (NCC), the mobile Internet access rate in Taiwan has exceeded $90 \%$. Mobile payments have gradually become a lifestyle, and the consumption pattern of e-commerce has been further enhanced by mobile commerce. Various ways of payments are constantly changing the consumers' payment habits. In daily life, it is necessary to use cash for transactions, which is not only inconvenient, but can be easily stolen. The extensive use of credit cards for everyday consumption tends to be a substitute for cash. However, as stated earlier, with the popularization of smartphones and the advancement of communication technology, innovative payment models for mobile payments have emerged, making payment methods move towards a cashless era. This would solve the inconvenience of consumers needing to carry cash with them and allow them to complete

a Prof., National ChiaYi University, Department of Business Administration, Taiwan, hideko@mail.ncyu.edu.tw (ORCID ID: 00000003-3927-6293)

b Assoc. Prof., National ChiaYi University, Department of Applied Economics, Taiwan, ley@mail.ncyu.edu.tw (ORCID ID: 00000002-6615-3101)

c Assoc. Prof., Lung Hwa University of Science and Technology, Department of Business Administration, Taiwan, shengju@mail.lhu.edu.tw (ORCID ID: 0000-0002-6687-0362)

d EMBA Degree, National Chiayi University, College of Management, Taiwan, mars710909@gmail.com (ORCID ID: 0000-00024556-1704) 
everyday payment transactions more conveniently, safely, and quickly. Hence, mobile payments have gradually formed a lifestyle, which is an important trend for future consumer behavior.

Mobile payment is the payment made on mobile devices through a mobile communication network (Lerner, 2013; Téllez \& Zeadally, 2017). Mobile payment is divided into two types: proximity payment and remote payment (Srivastava, Chandra, \& Theng, 2010). Proximity payments are usually used in point of sale processes, such as NFC induction or scanning payments. The remote payment is usually used in e-commerce and is without geographical restrictions, such as financial transfers or international remittances (Téllez \& Zeadally, 2017). Regarding mobile payments in Taiwan, according to the current laws, the main features of mobile payments are electronic payments, electronic tickets, and third-party payments. Hence, credit card payments will be transferred using electronic payments, electronic tickets or mobile devices without using cashes. The electronic ticket or mobile device set the consumer's credit card and/or bank account number in the payment method provided by the mobile device.

According to the Banking Bureau of the Financial Supervisory Commission (2020), due to the improvement of Taiwan's financial infrastructure, by January 2020, the number of ATMs in Taiwan reached 30,580 , and the number of financial institutions had reached 6,215. During this period, people have not changed their habits of paying in cash. Research data shows that the number of mobile payments applications in North America and Europe is still the highest in the world. This is because European and American countries have open regulatory models, innovative business models, high credit card penetration rates, and relatively stable growth trends of mobile payments. In comparison, the Asian region has grown more rapidly, especially in Mainland China, South Korea and Japan where growth is more than $20 \%$ over two consecutive years. According to statistics from the Financial Supervisory Commission, in 2016, the amount of mobile payment transactions was NT\$1.49 billion (statistics started in March), NT\$14.8 billion in 2017 and NT\$47.8 billion in 2018. Statistics for the first 11 months of 2019 is NT\$103 billion, which shows that more and more consumers are actively starting to use mobile payments. According to the statistics of the Banking Bureau of the Financial Management Commission, by the end of December 2019, there are five franchises supporting electronic payments in Taiwan including JKOPAY, O'Pay, GAMA PAY, PChomePay, and ezPay and 23 part-time operators such as banks, post offices and electronic ticket issuing institutions. The total number of users had reached 6.92 million, an increase of 2.62 million from 2018 and an annual growth of $60.93 \%$. This shows that the convenience of mobile payments has changed consumers' payment habits.

The convenience of mobile payments and changes in consumer consumption patterns have raised awareness of many banks about the huge business opportunities behind mobile payments and subsequently they have actively invested in and developed their own brand of mobile payments APPs to seize the mobile payment market. However, the usage methods, regulations, supporting banks, and discounting activities of various banks' mobile payment systems are diversified. In Taiwan, high density of ATMs and popularity of credit cards make consumers prefer to use ATMs and/or credit cards over mobile payments APPs, and this has always been a concern to the banks.

The Information Policy Commission has found that Taiwanese mobile payment users willing to continue using it, is $98.7 \%$, and even $71.1 \%$ of non-users have expressed their willingness to try it in the future. However, $22 \%$ of users stated that their accounts have been deleted or deactivated, and the main reasons for this are, in order, "businesses with mobile payments are not common (45.7\%)", "concessions are not ideal (44.3\%)" and "system is unstable (27.1\%)". In addition, the reasons that affect the use are security (53.1\%), convenience (34.7\%), discounts (32.6\%), ease of use (31\%), and popularity (30.5\%). Dahlberg et al. (2015) reviewed the relevant research on mobile payments from 2006 to 2015, and pointed out that security is an important prerequisite for using it, and exploring consumers' intentions is still one of the most important research topics. Therefore, it can be seen that security is one of the most important factors consumers pay attention to when using mobile payments.

The consumption value refers to the degree of consumer demand for the utility brought by commodities, and is the main reason why consumers choose products or brands. Gallouj (2002) believes that if companies can continue to be innovative on their services and use customers' experiences to modify the 
technology accordingly, they can potentially create more value for consumers. The premise is that brands should continue to enhance the consumption value. Gil, Berenguer, and Cervera (2008) point out that consumers usually use technology to enhance the value after use, and this value is generated by consumers' feelings and experiences. Therefore, in addition to understanding consumers' perceptions and usage behavior of mobile payments, the correlation between consumption value and usage behavior is also extremely important.

The Financial stability board (2018) believes that whether mobile payments are accepted by users is affected by two factors: supply side and demand side. The former is whether the new technology is sufficient to support financial innovation and the financial regulatory environment is friendly to financial innovation. The latter focuses on user acceptance and preferences. Therefore, this study uses perceived ease of use, perceived usefulness, and usage behavior in the technology acceptance model (TAM) as all of its research variables. The security and functional consumption value will also be included in the research. Although there are many influential factors on the use of mobile payments from past literature (Mallat, Rossi, \& Tuunainen, 2004; Nysveen et al., 2005; Kanniainen, 2010; Kim, Mirusmonov, \& Lee, 2010; Shin, 2010; Mohammadi et al., 2011; Kapoor, Dwivedi, \& Williams, 2014), there is a lack of research taking into account both influencing factors and consumption value. Additionally, in order to enable banks to stand out in the mobile payments market, exploring and understanding the influencing factors of consumers' choices of mobile payments APPs has become the primary issue for banks to promote their own mobile payments Apps. Through this research, the relationships among security, perceived usefulness, perceived ease of use, functional consumption value and usage behavior were scrutinized then consumers' usage behavior for mobile payments was inferred. It is expected that the research results can be served as references for banks for designing mobile payments APPs.

\section{Literature Review}

\subsection{Mobile Payment}

Dahlberg et al. (2008) define mobile payment as the payment process for transactions such as goods, services, payment of bills, etc. using mobile devices such as smart phones, wireless functions of PDAs and other communication functions. Remco and Tonnis (2009) believe that mobile payment is the payment of goods and labor transactions using mobile devices, such as point-of-sale (POS) systems on mobile phone sensor shops for consumption and payment, online personal remittance lending (Peer-to-Peer Lending, P2P) and eCommerce (consumer-to-business: $\mathrm{C2B}$ ) are all included in the scope of mobile payments. Miao and Jayakar (2016) believe that mobile payments are made through the use of mobile telecommunications networks or near-field communication, and the use of mobile devices to pay for goods, services, bills, and invoices. Liébana-Cabanillas and Lara-Rubio (2017) states that mobile payment APPs are an electronic device that connects the payment process to the mobile network and completes economic transactions with any type of personal or commercial activity.

\subsection{Technology Acceptance Model}

The technology acceptance model (TAM) is a set of theories developed by Davis, Bagozzi and Warshaw (1989), which use the theory of rational behavior proposed by Fishbein and Ajzen in 1975 as the basis and adaptation of using information technology. At the time, perceived usefulness and perceived ease of use are the determinants that affect the user's intention. The TAM is primarily used to examine the influences of perceived usefulness and perceived ease of use on the attitude toward using, behavioral intention to use and actual system use of the technology. The TAM can also use external variables to analyze their influences on the user's beliefs, attitudes and willing. The conceptual architecture of the TAM is shown in Figure 1.

The perceived usefulness refers to the user's subjective determination in using this technology will increase work efficiency, make work easier, and be helpful in making life more convenient. The perceived ease of use means that when users use a certain system, they perceive that the technology is easy to use or 
learn. If the technology can be easily used then users will become more confident as their competence improves, and their attitudes toward using the system will also become more positive. Consumers expect that technology can help improve their performance, and enhance their positive perception of technology products, which will encourage others to use them. The use of the system is mainly influenced by the user's will. The higher the will, the stronger the decision to accept the use of the technology, which will ultimately affect the actual behavior of using information technology. Davis (1989) believes that external variables directly affect perceived usefulness and perceived ease of use, and indirectly affect users' attitudes and willingness to use.

Figure 1. The Technology Acceptance Model (Version 1)

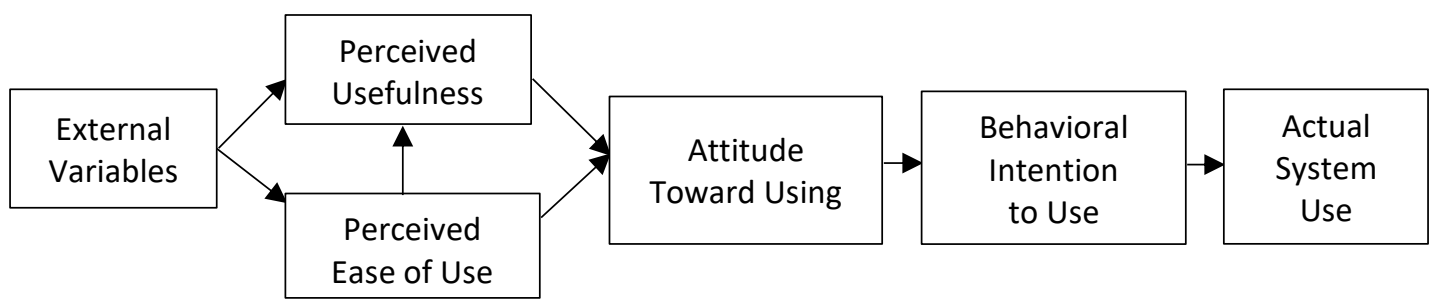

Source: Davis, Bagozzi, \& Warshaw (1989).

Adams (1992) and Straub, Limayem, and Karahanna (1995) proposed a revised version of the TAM, in which the behavior intention was deleted. Furthermore, this was supported by the research results which verified that the user's perceived usefulness of information technology will directly affect their attitude and actual system use. The conceptual structure is shown in Figure 2.

Figure 2. The Technology Acceptance Model (Revised Version)

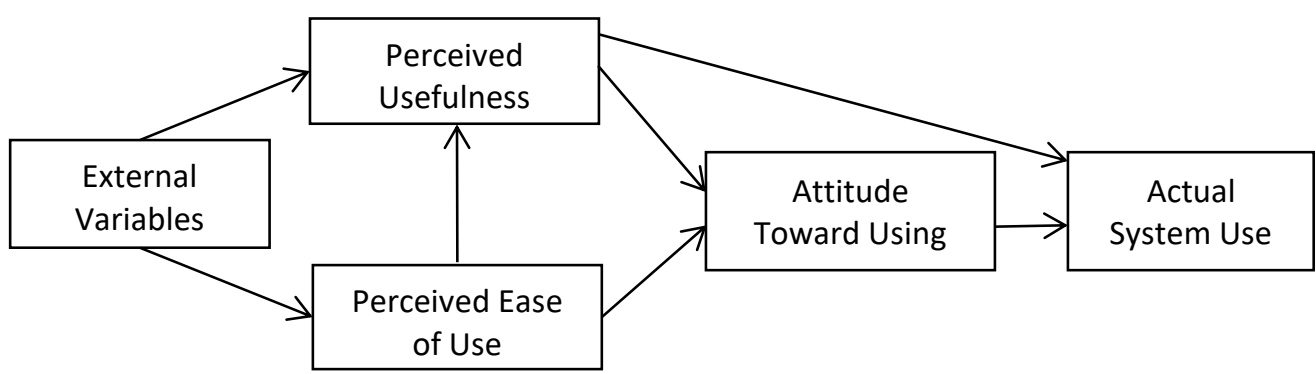

Source: Adams (1992); Straub, Limayem, \& Karahanna (1995).

\subsection{Consumption Values}

Sheth, Newman, and Gross (1991) put forward a consumption values and market choices theory, which focuses on consumers' purchase motivation. Sheth et al. (1991) stresses that consumers will face three choice behaviors. The three choice behaviors are "products to buy vs. not to buy", "product type", and "brand choice". These choice behaviors will be determined according to the five consumption value dimensions of the product. Each consumption value dimension is briefly described as follows:

1. Functional value refers to the most fundamental value when consumers choose commodities, and this value focuses on the actual feelings that consumers have on products or services after purchase or use. Therefore, the value of the product or service can be measured by its functional attributes. 
2. Social value means whether consumers will be affected by the perceptions or experiences of the public when they choose products or services. Therefore, the value of a product or service can be measured through its social image.

3. Emotional value means the personal emotions experienced by consumers after purchasing products or services. Therefore, the value of consumers can be measured by their continuous perception of the product or service.

4. Epistemic value refers to consumer's behavior that causes curiosity or freshness due to the effectiveness of the product or service. Therefore, its value can be measured by the consumer's pursuit of expectations for the product or service.

5. Conditional value means whether consumers will make a difference in perception of the target product or service due to special circumstances during its use. Therefore, its value can be measured through the occasional situation.

Functional value is a factor that consumers give priority to when making purchasing decisions. Consumers choose mobile payments as a payment method because the functional value in this instance, meets consumers' time-saving and labor-saving needs. User behavior is affected by functional value. Therefore, this study uses Sheth et al. (1991) functional value for consumption value theory, to explain whether consumers use a product or service when presented with it. In addition, it further explores that whether or not consumer behavior will be enhanced through functional value when mobile payments APPs is security, perceived usefulness, and perceived ease of use.

\subsection{Research Hypotheses}

Davis (1989) and Davis et al. (1989) proposed that external factors will affect the user's personal beliefs (perceived usefulness and perceived ease of use). Personal beliefs will affect the user's attitude and willingness, which in turn affects the use of information systems. Users are most worried about data privacy and data security when using payment systems. If they can be properly protected so that the data is not stolen or released, users will be assured that they do not need to spend too much effort and time to study how to prevent data leakage. This study proposes Hypothesis 1 and Hypothesis 2.

$H_{1}$ : Security positively influences perceived usefulness.

$\mathbf{H}_{\mathbf{2}}$ : Security positively influences perceived ease of use.

Sparing time and effort on learning payment software and convenient operations can improve users' work performance and efficiency. Davis (1993), Moon and Kim (2001), Wu and Wang (2005), Bruner and Kumar (2005) show that the perceived ease of use will positively affect the perceived usefulness. Therefore, this study proposes Hypothesis 3.

$\mathbf{H}_{3}$ : Perceived ease of use positively influences perceived usefulness.

Flint, Woodruff, and Gardial (1997) pointed out that service innovation will affect customer value. Weerawardena (2003) claimed that innovation will have a positive impact on the organization's value chain and subsequently create consumer value. When users think that mobile payment is useful and easy to use, it will directly affect the consumption value. Therefore, this study proposes Hypothesis 4 and Hypothesis 5.

$\mathbf{H}_{4}$ : Perceived usefulness positively influences functional consumption value.

$\mathbf{H}_{5}$ : Perceived ease of use positively influences functional consumption value.

Brown (1990) stated that if the services provided by an enterprise can increase consumer value, it will increase consumers' use of the service. From the consumer's point of view, consumers will be affected individually or in total by the five values in the process of purchasing goods (Sheth et al., 1991). Solomom (2007) thought that consumers buy many products and services because they believe that these products help achieve a value-related purpose. Therefore, this study proposes Hypothesis 6. 
$\mathbf{H}_{6}$ : Functional consumption value positively influences usage behavior.

Davis (1993), Moon and Kim (2001), Wu and Wang (2005) and some other researchers found that when consumers use specific technologies and it improves their work performance, they will think that the technology has perceived usefulness, thereby increasing their willingness to use it. Wen, Prybutok, and Xu (2011) declared that the perceived usefulness has the greatest impact on purchasing intentions and is an intervening variable of trust and repurchase intention. It implies that consumers will use them more often if they think mobile payments are useful. Therefore, this study proposes Hypothesis 7.

$\mathbf{H}_{7}$ : Perceived usefulness positively influences usage behavior.

\section{Research Methodology}

\subsection{Conceptual Framework and Hypotheses}

These variables build up a conceptual framework and research hypotheses with the objectives of this study. Figure 3 illustrates a schematic diagram that represents the conceptual framework of this study. The variables mainly include security, perceived usefulness, perceived ease of use, functional consumption value, and usage behavior.

Figure 3. Conceptual Model

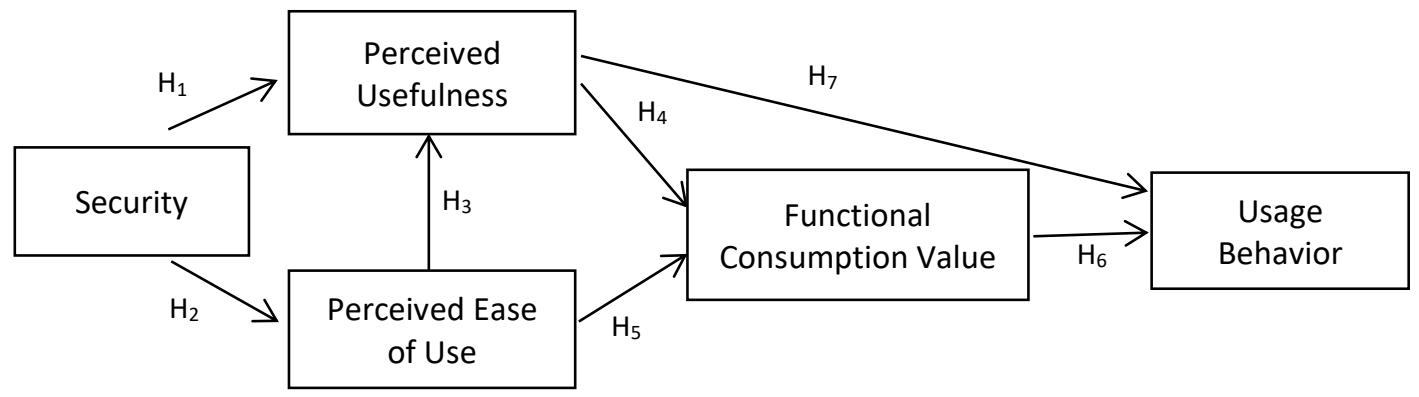

\subsection{Questionnaire Design}

The relevant variables affecting consumers' behavior of mobile payments are first screened out. Then, referring to the previous related studies including Sheth et al. (1991), Venkatesh and Davis (2000), Tan and Teo (2000), Chen (2008), and Liu et al. (2011), the bank's mobile payment APPs scale was designed. There are 6 parts in the questionnaire. The first part is measured by the nominal scale, whilst the second to sixth parts are all measured using Likert's five-point scale. Scores of 1 to 5 will be given by respondents according to their degree of consent. On the scale of 1 to 5, 1 represents "strongly disagree" and 5 represents "strongly agree".

\section{Data Analysis}

\subsection{Data Collection and Sample Statistics}

The research questionnaires apply convenience sampling method to survey. The data collection was carried out by the GOOGLE online questionnaire system from May 17, 2019 to May 30, 2019. A total of 300 respondents completed usable questionnaires.

In Table 1 it can be seen that more than half the respondents are women (50.7\%). About $63.7 \%$ respondents have a university (college) education level. The largest age group is between 31-40 years old, which accounts for $48.3 \%$. $31.7 \%$ of respondents have an occupation in the service industry. Most of the respondents have average monthly income between NT\$25,001-40,000, accounting for $33 \%$. 
As shown in Table 2, in terms of usage behavior, most users make use of mobile phone apps less than 5 times a week, accounting for $49 \%$. Those who use them for 6 to 8 times account for $40.3 \%$ and the time for respondents to start using bank's mobile payments APPs was mostly within one to two years (41.0\%). This was followed by more than half a year to one year (28.7\%). The highest amount of expense was between NT\$1,001 to 3,000, accounting for $41.0 \%$ of respondents. The largest group for credit card payment habits accounted for $44.7 \% .54 .3 \%$ of mobile phone operating systems is IOS (iPhone). Most of the respondents use only one kind of bank's mobile payment APPs, accounting for $49.7 \%$.

Table 1. Frequency Distribution of Sample Characteristics

\begin{tabular}{|c|c|c|c|}
\hline $\begin{array}{l}\text { Participant } \\
\text { Characteristics }\end{array}$ & Items & Frequency & Percent \\
\hline \multirow{2}{*}{ Gender } & Male & 148 & 49.3 \\
\hline & Female & 152 & 50.7 \\
\hline \multirow{3}{*}{ Education } & High School diploma or less & 54 & 18.0 \\
\hline & University & 191 & 63.7 \\
\hline & Post University & 55 & 18.3 \\
\hline \multirow{5}{*}{ Age } & Less than 20 & 7 & 2.3 \\
\hline & $21-30$ & 56 & 18.7 \\
\hline & $31-40$ & 145 & 48.3 \\
\hline & $41-50$ & 69 & 23.0 \\
\hline & above 51 & 23 & 7.7 \\
\hline \multirow{9}{*}{ Occupation } & Manufacturing & 49 & 16.3 \\
\hline & Information Industry & 26 & 8.7 \\
\hline & Financial Industry & 50 & 16.7 \\
\hline & Service Industry & 95 & 31.7 \\
\hline & Military Education & 18 & 6.0 \\
\hline & Freelance & 25 & 8.3 \\
\hline & Housewife & 14 & 4.7 \\
\hline & Medical Industry & 12 & 4.0 \\
\hline & Others & 11 & 3.7 \\
\hline \multirow{7}{*}{ Income per Monthly } & Less than 25,000 & 18 & 6.0 \\
\hline & $25,001-40,000$ & 99 & 33.0 \\
\hline & $40,001-55,000$ & 76 & 25.3 \\
\hline & $55,001-70,000$ & 55 & 18.3 \\
\hline & $70,001-85,000$ & 15 & 5.0 \\
\hline & $85,000-100,000$ & 18 & 6.0 \\
\hline & above 100,001 & 19 & 6.3 \\
\hline
\end{tabular}

Table 2. Consuming Behavior Analysis of Sample

\begin{tabular}{llcc}
\hline $\begin{array}{l}\text { Consuming } \\
\text { Behavior }\end{array}$ & Items & Frequency & Percent \\
\hline \multirow{3}{*}{ Weekly Frequency } & less than 5 & 147 & 49.0 \\
& $9-8$ & 121 & 40.3 \\
& Above 15 & 11 & 3.7 \\
\hline \multirow{2}{*}{ Use time for } & less than 1 & 21 & 7.0 \\
Mobile Payment & $1-2$ & 86 & 28.7 \\
Apps & $2-3$ & 123 & 41.0 \\
& Above 3 & 51 & 17.0 \\
\multirow{2}{*}{ Amount } & less than 1,000 & 40 & 13.3 \\
Consumption & $1,001-3,000$ & 86 & 28.7 \\
& $3,001-5,000$ & 123 & 41.0 \\
\hline
\end{tabular}


Table 2. Consuming Behavior Analysis of Sample (Continued)

\begin{tabular}{llcc}
\hline \multirow{3}{*}{ Payment Habits } & Cash & 109 & 36.3 \\
& Credit Card & 134 & 44.7 \\
& Mobile Payment & 57 & 19.0 \\
\hline \multirow{2}{*}{ Cellphone System } & Android & 137 & 45.7 \\
& IOS & 163 & 54.3 \\
\hline \multirow{4}{*}{ Cellphone Brand } & APPLE & 163 & 54.3 \\
& SAMSUNG & 51 & 17.0 \\
& OPPO & 20 & 6.7 \\
& SONY & 17 & 5.7 \\
& Xiaomi & 12 & 4.0 \\
\multirow{3}{*}{ Numbers of Mobile } & Others & 37 & 12.3 \\
Payment Apps & 1 & 149 & 49.7 \\
& $2-3$ & 119 & 39.7 \\
& $4-5$ & 23 & 7.7 \\
\hline
\end{tabular}

\subsection{Descriptive Statistics of Dimensions}

As shown in Table 3, the average value of each dimension is between 3.92-4.43, and the standard deviation (S.D.) is between 0.67-0.89. Among them, security ( $M=4.1444)$, perceived usefulness $(M=4.4325)$, perceived ease of use $(M=4.4058)$, and functional consumption value $(M=4.3117)$ all received relatively high evaluations. It indicates that users generally agree that bank's mobile payments APPs are helpful since they are easy to use, safe to use, and present practical and functional values. Therefore, when bank's mobile payments APPs are security, usefulness, ease to use, and functional consuming value, consumers will choose bank's mobile payment APPs.

Table 3. Descriptive Statistics of Constructs

\begin{tabular}{lcc}
\hline Dimension & Mean & S.D. \\
\hline Security & 4.1444 & 0.7878 \\
Perceived Usefulness & 4.4325 & 0.6725 \\
Perceived Ease of Use & 4.4058 & 0.6737 \\
Functional Consumption Value & 4.3117 & 0.6745 \\
Usage Behavior & 3.9256 & 0.8869 \\
\hline
\end{tabular}

\subsection{Overall Model Verification and Path Analysis}

\subsubsection{Measurement Model}

The measurement model is designed to evaluate whether each measurement index in the model correctly measures the potential variables, and to check whether there are complex measurement indexes that are loaded with different potential variables, that is, to verify the convergent validity and discriminant validity. Using confirmatory factor analysis to evaluate the measurement model, the results of reliability and validity analysis are summarized in Table 4 and Table 5 . The standardized factor loading (SFL) of each dimension/item is greater than 0.5 , indicating that the observed variable is sufficient to reflect the potential variable (Hair et al., 1998). The credibility of Cronbach's a coefficient is between $0.703-0.830$, both exceeding the 0.7 level. The composite reliability (CR) of each dimension is between $0.7550-0.8984$, which is higher than 0.6 (Fornell \& Larcker, 1981; Bagozzi \& Yi, 1988; Hair et al., 1998). The average variance extracted (AVE) is between $0.5629-0.8876$, which satisfies the critical criterion of 0.5 by Fornell and Larker (1981). 
Table 4. Construct and Scale Items Measures in the Study

\begin{tabular}{|c|c|c|c|c|c|}
\hline Dimension and Items & SFL & SMC & CR & AVE & Cronbach's $\alpha$ \\
\hline Security & & & 0.7550 & 0.8876 & 0.703 \\
\hline Transaction Security Certification & 0.712 & 0.5069 & & & \\
\hline Personal Information Protection & 0.823 & 0.6773 & & & \\
\hline Payment with Biometrics & 0.785 & 0.6162 & & & \\
\hline Perceived Usefulness & & & 0.8984 & 0.6889 & 0.830 \\
\hline $\begin{array}{c}\text { Number of partner merchants that } \\
\text { can use mobile payment Apps }\end{array}$ & 0.804 & 0.6464 & & & \\
\hline \multicolumn{6}{|l|}{ Transaction Fast } \\
\hline No Cash or Credit & 0.855 & 0.7310 & & & \\
\hline \multirow{2}{*}{ Internationally Available } & 0.830 & 0.6889 & & & \\
\hline & 0.777 & 0.6037 & & & \\
\hline Perceived Ease of Use & & & 0.8783 & 0.6439 & 0.808 \\
\hline No additional devices required & 0.776 & 0.6022 & & & \\
\hline Operation is clear and simple & 0.839 & 0.7039 & & & \\
\hline $\begin{array}{l}\text { Supports various mobile operating } \\
\text { systems }\end{array}$ & 0.760 & 0.5776 & & & \\
\hline $\begin{array}{l}\text { A single account can be used on } \\
\text { different cellphones }\end{array}$ & 0.774 & 0.5991 & & & \\
\hline Functional Consumption Value & & & 0.8536 & 0.6009 & 0.758 \\
\hline $\begin{array}{l}\text { There is a single cap control or total } \\
\text { limit to the amount of use }\end{array}$ & 0.835 & 0.6972 & & & \\
\hline Cash back with mobile payment & 0.869 & 0.7552 & & & \\
\hline $\begin{array}{l}\text { Through the integration of different } \\
\text { industries, mobile payment APPs } \\
\text { provide payment methods for } \\
\text { non-ordinary merchants }\end{array}$ & 0.822 & 0.6757 & & & \\
\hline Convenient Consumption & 0.527 & 0.2777 & & & \\
\hline Usage Behavior & & & 0.7940 & 0.5629 & 0.726 \\
\hline $\begin{array}{l}\text { Compared with cash, I will give } \\
\text { priority to mobile payment }\end{array}$ & 0.854 & 0.7293 & & & \\
\hline $\begin{array}{l}\text { Compared with credit card, I will } \\
\text { give priority to mobile payment }\end{array}$ & 0.852 & 0.7259 & & & \\
\hline Reduction of inter-band handling & & & & & \\
\hline $\begin{array}{l}\text { fees, I will give priority to mobile } \\
\text { payment }\end{array}$ & 0.772 & 0.5960 & & & \\
\hline
\end{tabular}

Table 5. Intercorrelation Among Study Variables

\begin{tabular}{lccccc}
\hline Dimension & Security & $\begin{array}{c}\text { Perceived } \\
\text { Usefulness }\end{array}$ & $\begin{array}{c}\text { Perceived } \\
\text { Ease of } \\
\text { Use }\end{array}$ & $\begin{array}{c}\text { Functional } \\
\text { Consumption } \\
\text { Value }\end{array}$ & $\begin{array}{c}\text { Usage } \\
\text { Behavior }\end{array}$ \\
\hline Security & 0.9421 & & & & \\
Perceived Usefulness & 0.6780 & 0.8300 & & & \\
Perceived Ease of Use & 0.7400 & 0.8340 & 0.8024 & & \\
Functional Consumption Value & 0.6130 & 0.7170 & 0.7060 & 0.7752 & 0.7503 \\
Usage Behavior & 0.4080 & 0.5560 & 0.5440 & 0.5730 & \\
\hline
\end{tabular}

Note: The diagonal value is the square root of the average extraction variation of the dimension, the non-diagonal value is the correlation coefficient between each dimension. 
Regarding the verification of discriminant validity, the judgment criterion of this study is that the square root of AVE of each dimension is greater than the number of correlation coefficients for each dimension, accounting for at least $75 \%$ of the total comparison number (Hair et al., 1998), which can be found from Table 5. The square root of the AVE of each dimension is between $0.7503-0.9421$, and a value of more than $75 \%$ is greater than the correlation coefficient between the dimensions. This analysis result shows that each dimension meets the judgment criteria, indicating that the dimensions have enough discriminant validity.

\subsubsection{Structural Equation Model}

The structural equation model (SEM) is adopted to test the goodness of fit for the model. The results are summarized in Table 6 . It shows that all of the fit indexes including degree of freedom $\left(x^{2} / d . f.\right)$, goodness of fit index (GFI), root mean square residual, RMR), adjusted goodness of fit index (AGFI), normed fit index (NFI), relative fit index (RFI), incremental fit index (incremental fit index, IFI), non-normed fit index (NNFI), and comparative fit index (comparative fit index, CFI) meet the level required by the recommended value. Therefore, the goodness of fit of the theoretical model proposed by the research is considered quite acceptable.

Table 6. Summary of Model Fit Indexes

\begin{tabular}{lccc}
\hline & Fit Index & $\begin{array}{c}\text { Recommended } \\
\text { Value }\end{array}$ & Value \\
\hline \multirow{3}{*}{ Absolute Fit } & $x^{2} /$ d.f. & $1-5$ & 3.655 \\
Measurement & GFI & $\geqq .9$ & 0.985 \\
& RMR & $<.08$ & 0.011 \\
& AGFI & $\geqq 0.9$ & 0.927 \\
\hline Incremental Fit & $\mathrm{NFI}$ & $\geqq 0.9$ & 0.989 \\
Measurement & $\mathrm{RFI}$ & $\geqq 0.9$ & 0.963 \\
& $\mathrm{IFI}$ & $\geqq 0.9$ & 0.992 \\
& $\mathrm{CFI}$ & $\geqq 0.9$ & 0.992 \\
\hline
\end{tabular}

The relationships among potential variables were further examined based on the verified model. The standardized coefficients of hypothesis tests are summarized in Table 7. Security has a significant positive effect on the perceived usefulness $(\beta=0.135 ; \mathrm{P}<0.01)$, so as Hypothesis 1 holds. Hypothesis 2 holds true that security has a significant positive effect on perceived ease of use $(\beta=0.740 ; P<0.001)$. Hypothesis 3 is sustained since perceived ease of use has a significant positive effect on perceived usefulness $(\beta=0.735 ; P$ $<0.001)$. Perceived usefulness has a significant positive effect on functional consumption value $(\beta=0.422$; $\mathrm{P}<0.001$ ), which implies that Hypothesis 4 holds. Hypothesis 5 holds true because perceived ease of use has a significant positive effect on functional consumption value $(\beta=0.354 ; \mathrm{P}<0.001)$. Functional consumption value has a significant positive effect on usage behavior $(\beta=0.358 ; P<0.001)$, indicating Hypothesis 6 is sustained supported. Perceived usefulness has a significant positive effect on usage behavior $(\beta=0.299$; $\mathrm{P}<0.001)$, so as Hypothesis 7 holds. The research results show that users believe that bank's mobile payment APPs are useful and easy to use because of the effect of security. The functional consumption value is significantly affected by perceived usefulness and perceived ease of use. The functional consumption value will significantly positively affect usage behavior. When users feel safe to use bank's mobile payment APPs and they do not need to spend too much time and effort to learn operations, it will make them feel that they have more functional consumption value, and hence they will choose mobile payments as a payment method. 
Table 7. Path Analysis Results

\begin{tabular}{lr}
\hline \multicolumn{1}{c}{ Path } & Standardized Path Estimate \\
\hline $\mathrm{H}_{1}:$ Security $\rightarrow$ Perceived Usefulness & $0.135^{* *}$ \\
$\mathrm{H}_{2}:$ Security $\rightarrow$ Perceived Ease of Use & $0.740^{* * *}$ \\
$\mathrm{H}_{3}:$ Perceived Ease of Use $\rightarrow$ Perceived Usefulness & $0.735^{* * *}$ \\
$\mathrm{H}_{4}:$ Perceived Usefulness $\rightarrow$ Functional Consumption Value & $0.422^{* * *}$ \\
$\mathrm{H}_{5}:$ Perceived Ease of Use $\rightarrow$ Functional Consumption Value & $0.354^{* * *}$ \\
$\mathrm{H}_{6}:$ Functional Consumption Value $\rightarrow$ Usage Behavior & $0.358^{* * *}$ \\
$\mathrm{H}_{7}:$ Perceived Usefulness $\rightarrow$ Usage Behavior & $0.299^{* * *}$ \\
\hline Note: $* *$ and $* * *$ denote the $0.01,0.001$ significant level respectively. &
\end{tabular}

\section{Conclusions}

The results show that on the usage behavior of bank's mobile payment, the results are consistent with other studies (Senso \& Venkatakrishnan, 2013; Lwoga \& Lwoga, 2017). Consumers' usage behavior is positively influences by perceived usefulness and functional consumption value; functional consumption value is positively influences by perceived usefulness and perceived ease of use. Hence, our results suggest the dominance of perceived usefulness over perceived ease of use in forming consumers' functional consumption value. The finding that perceived ease of use had significant positive relationship with the perceived usefulness is similar with other studies (Davis, 1989; Kim et al., 2010; Lwoga \& Lwoga, 2017). Another significant finding was the positive effects of perceived usefulness on consumer's usage behavior, which is same as other previous studies (Tobbin \& Kuwornu, 2011; Hamza, 2014).

The results found that if the bank's mobile payments APPs is security, it can make the users feel at ease and relaxed during use and have a good impression. When the user is comfortable with the APPs they will feel that the bank's mobile payments APPs is a useful part of their life, especially, when shopping. When the user feels that the bank's mobile payments APPs is useful, easy to use, and has a good impression, it will let the user experience the physical or functional value of the bank's mobile payments APPs. During bank transactions, if the payment app can satisfy consumers with the purposes of bank's mobile payments APPs, then consumers would prioritize its use when shopping or in general life. If the user believes that using the bank's mobile payments APPs can improve the quality of life and work performance, they will prefer to use the bank's mobile payments APPs first.

In order to popularize the use of mobile payments APPs in Taiwan, mobile payments APPs developers need to think about how to provide a safe, useful, and easy-to-use environment and operating interfaces to meet the consumer value that users can obtain and then use it. For example, constantly increasing the number of cooperative merchants using mobile payments APPs, supporting various mobile phone operating systems, ensuring convenient and fast transaction speeds, preventing personal data been leaked, etc. are ways to encourage users to continue their use. In addition, the user operating interfaces must be simpler and clearer, so that users can feel the user-friendliness of bank's mobile payment APPs. Nowadays, since fraud incidents frequently occur, consumers have great concerns about security. Therefore, the design of security must be more rigorous, so that users can use it with confidence. 


\section{Disclosure Statements}

1. The authors of this article confirm that their work complies with the principles of research and publication ethics.

2. No potential conflict of interest was reported by the authors.

3. This article was screened for potential plagiarism using a plagiarism screening program.

\section{References}

Banking Bureau of the Financial Supervisory Commission (2020). Financial Statistics Abstract. Banking Bureau, Financial Supervisory Commission

Adams, D. A., Nelson, R. R., \& Todd, P. A. (1992). Perceived usefulness, ease of use, and usage of information technology: A replication. MIS Quarterly, 16(2), 227-247.

Bagozzi, R. P., \& Yi, Y. (1988). On the evaluation of structural equation models. Academic of Marketing Science, 16(1), 76-94.

Brown, L. G. (1990). Convenience in services marketing. Journal of Services Marketing, 4(1), 53-59.

Bruner, G. C., \& Kumar, A. (2005). Explaining consumer acceptance of handheld internet devices. Journal of Business Research, 58(5), 553-558.

Chen, L. d. (2008). A model of consumer acceptance of mobile payment. International Journal of Mobile Communications, 6(1), 32-52.

Dahlberg, T., Mallat, N., Ondrus, J., \& Zmijewska, A. (2008). Past, present and future of mobile payments research: A literature review. Electronic Commerce Research and Applications, 7(2), 165-181.

Dahlberg, T., Guo, J., \& Ondrus, J. (2015). A critical review of mobile payment research. Electronic Commerce Research and Applications, 14(5), 265-284.

Davis, F. D. (1989). Perceived usefulness, perceived ease of use, and user acceptance of information technology. MIS Quarterly, 13(3), 318-340.

Davis, F. D., Bagozzi, R. P., \& Warshaw, P. R. (1989). User acceptance of computer technology: A comparison of two theoretical models. Management Science, 35(8), 982-1002.

Davis, F. D. (1993). User acceptance of information technology: System characteristics, user perceptions, and behavioral impacts. International Journal of Man Machine Studies, 38(3), 475-487.

Financial Stability Board. (2018). Global shadow banking monitoring report 2017. Retrieved from https://www.fsb.org/terms_conditions/

Fishbein, M., \& Ajzen, I. (1975). Belief, attitude, intention, and behavior: An introduction to theory and research. Reading. MA: Addison-Wesley.

Flint, D. J., Woodruff, R. B., \& Gardial, S. F. (1997). Customer value change in industrial marketing relationships. Industrial Marketing Management, 26(2), 163-175.

Fornell, C., \& Larker, D. (1981). Evaluating structural equation methods with unobservable variables and measurement error. Journal of Marketing Research, 18(1), 39-50.

Gallouj, F. (2002). Innovation in the service economy: The new wealth of nations. Cheltenham: Edward Elgar

Gil, I., Berenguer, G., \& Cervera, A. (2008). The roles of service encounters, service value, and job satisfaction in achieving customer satisfaction in business relationships. Industrial Marketing Management, 37(8), 921-939.

Hair, J. F. Jr., Anderson, R. E., Tatham, R. L., \& Black, W. C. (1998). Multivariate data analysis (5 $5^{\text {th }}$ ed.). London, England: Pearson Education Press.

Hamza, A., \& Shah, A. (2014). Gender and mobile payment system adoption among students of tertiary institutions in Nigeria. International Journal of Computer and Information Technology, 3(1), 13-20.

Kanniainen, L. (2010). Alternatives for banks to offer secure mobile payments. International Journal of Bank Marketing, 28(5), 433-444.

Kapoor, K. K., Dwivedi, Y. K., \& Williams, M. D. (2014). Examining the role of three sets of innovation attributes for determining adoption of the interbank mobile payment service. Information Systems Frontiers, 17, 1039-1056. 
Kim, C., Mirusmonov, M., \& Lee, I. (2010). An empirical examination of factors influencing the intention to use mobile payment. Computers in Human Behavior, 26(3), 310-322.

Lerner, T. (2013). Mobile payment. Springer.

Liébana-Cabanillas, F., \& Lara-Rubio, J. (2017). Predictive and explanatory modeling regarding adoption of mobile payment systems. Technological Forecasting and Social Change, 120, 32-40.

Liu, Y., Wang, S., \& Wang, X. (2011). A usability-centred perspective on intention to use mobile payment. International Journal of Mobile Communications, 9(6), 541-562.

Lwoga, E. T., \& Lwoga, N. B. (2017). User acceptance of mobile payment: The effects of user-centric security, system characteristics and gender. The Electronic Journal of Information Systems in Developing Countries, 81, 1-24.

Mallat, N., Rossi, M., \& Tuunainen, V. K. (2004). Mobile banking services. Communications of the ACM, 47(5), 42-46.

Miao, M., \& Jayakar, K. (2016). Mobile payments in Japan, South Korea and China: Crossborder convergence or divergence of business models? Telecommunications Policy, 40(2-3), 182-196.

Mohammadi, F., Baktash, L., Moghimi, R., \& Anvari, A. (2011). Perception of air travellers towards mobile ticketing: A case study in Malaysia. World Applied Sciences Journal, 12(5), 656-667.

Moon, J. W. \& Kim, Y. G. (2001). Extending TAM for a world-wide-web context. Information and Management, 38, 217230

Nysveen, H., Pedersen, P. E., Thorbjørnsen, H., \& Berthon, P. (2005). Mobilizing the brand: The effects of mobile services on brand relationships and main channel use. Journal of Service Research, 7(3), 257-276.

Remco, B., \& Tonnis, D. (2009). Mobile payments 2010 Market analysis and overview. Innopay Telecompaper, 1, 1-76.

Senso, N., \& Venkatakrishnan, V. (2013). Challenges of mobile-phone money transfer services' market penetration and expansion in Singida District, Tanzania. International Journal of Research in Management \& Technology, 3(6), 205-215.

Sheth, J. N., Newman, B. I., \& Gross, B. L. (1991). Why we buy what we buy: A theory of consumption values. Journal of Business Research, 22(2), 159-170.

Shin, D. H. (2010). Modeling the interaction of users and mobile payment system: Conceptual framework. International Journal of Human-Computer Interaction, 26(10), 917-940.

Solomon, M. R. (2007). Consumer behavior: Buying, having and being (Eighth Edition). Prentice Hall: NJ.

Srivastava, S. C., Chandra, S., \& Theng, Y. L. (2010). Evaluating the role of trust in consumer adoption of mobile payment systems: An empirical analysis. Communications of the Association for Information Systems, 27, 561-588.

Straub, D., Limayem, M., \& Karahanna, E. E. (1995). Measuring system usage: Implications for IS theory testing. Management Science, 41(8), 1328-1342.

Tan, M., \& Teo, T. S. H. (2000). Factors influencing the adoption of Internet banking. Journal of Association for Information Systems, 1(5), 1-42.

Téllez, J., \& Zeadally, S. (2017). Mobile payment systems: Secure network architectures and protocols. Cham: Springer International Publishing.

Tobbin, P., \& Kuwornu, J. K. M. (2011). Adoption of mobile money transfer technology: Structural equation modeling approach. European Journal of Business and Management, 3(7), 59-77.

Venkatesh, V., \& Davis, F. D. (2000). A theoretical extension of the technology acceptance model: Four longitudinal field studies. Management science, 46(2), 186-204.

Weerawardena, J. (2003). The role of marketing capability in innovation-based competitive strategy. Journal of Strategy Marketing, 11(1), 15-35.

Wen, C., Prybutok, V. R., \& Xu, C. (2011). An integrated model for customer online repurchase intention. Journal of Computer Information Systems, 52(1), 14-23.

Wu, J. H., \& Wang, S. C. (2005). What drives mobile commerce? An empirical evaluation of the revised technology acceptance model. Information \& Management, 42(5), 719-729.

Yang, S., Lu, Y., Gupta, S., Cao, Y. \& Zhang, R. (2012). Mobile payment services adoption across time: An empirical study of the effects of behavioral beliefs, social influences, and personal traits. Computers in Human Behavior, 28(1), 129-142.

Zarmpou, T., Saprikis, V., Markos, A., \& Vlachopoulou, M. (2012). Modeling users' acceptance of mobile services. Electronic Commerce Research, 12(2), 225-248. 
This Page Intentionally Left Blank 